\title{
Growth Factor-induced Acceleration of Tissue Repair through Direct and Inductive Activities in a Rabbit Dermal Ulcer Model
}

\author{
Thomas A. Mustoe," Glenn F. Pierce," Chihiro Morishima," and Thomas F. Deuels" \\ ${ }^{*}$ Departments of Surgery, ${ }^{8}$ Medicine, and 'Biochemistry and Molecular Biophysics, Barnes and Jewish Hospitals \\ at Washington University Medical Center, St. Louis, Missouri 63110; and "Department of Experimental Pathology, \\ Amgen, Inc., Thousand Oaks, California 91320
}

\begin{abstract}
The roles of polypeptide growth factors in promoting wound healing and in directing the specificity and sequence of responses of different tissues in wounds are little understood. We investigated the influence of four growth factors on the rates of healing of a novel full thickness dermal ulcer placed on an avascular base in the rabbit ear. The wound model precludes significant wound contraction and requires new granulation tissue and epithelial cells for healing to originate centripetally. $5 \mu \mathrm{g}$ (7-31 $\mathrm{pmol} / \mathrm{mm}^{2}$ ) of platelet-derived growth factor-B chain (PDGFBB), basic fibroblast growth factor (bFGF), and epidermal growth factor (EGF) applied locally at the time of wounding resulted in a twofold increase in complete reepithelialization of treated wounds (PDGF-BB, $P=0.02$ chi square analysis; bFGF, $P=0.04$; EGF, $P=0.05$ ); transforming growth factor (TGF)- $\beta 1$ significantly inhibited reepithelialization $(P=0.05)$. Both PDGF-BB and TGF- $\beta 1$ uniquely increased the depth and area of new granulation tissue $(P<0.005)$, the influx of fibroblasts, and the deposition of new matrix into wounds. Explants from 7-d old PDGF-BB-treated wounds remained metabolically far more active than controls, incorporating $473 \%$ more $\left[{ }^{3} \mathrm{H}\right]$ thymidine into DNA $(P=0.05)$ and significantly more $\left[{ }^{3} \mathrm{H}\right]$ leucine and $\left[{ }^{3} \mathrm{H}\right]$ proline into collagenase-sensitive protein $(P=0.04)$. The results establish that polypeptide growth factors have significant and selective positive influences on healing of full thickness ulcers in the rabbit. (J. Clin. Invest. 1991. 87:694-703.) Key words: growth factors $\bullet$ platelet-derived growth factor (PDGF) • wound healing • inflammation
\end{abstract}

\section{Introduction}

Platelet-derived growth factor (PDGF $)^{1}$, epidermal growth factor (EGF), transforming growth factor alpha (TGF- $\alpha$ ), basic fibroblast growth factor (bFGF), and transforming growth factor- $\beta 1$ (TGF- $\beta 1$ ) are polypeptide growth factors that have significant activity in tissue repair processes. These polypeptide

Address reprint requests to Dr. Thomas Deuel, Jewish Hospital, 216 South Kingshighway, St. Louis, MO 63110. 1990.

Received for publication 16 June 1990 and in revised form 7 August

1. Abbreviations used in this paper: EG, epithelial gap; EGF, epidermal growth factor; GTG, granulation tissue gap; MH, maximum height; PDGF, platelet-derived growth factor; TGF, transforming growth factor.

J. Clin. Invest.

(c) The American Society for Clinical Investigation, Inc.

$0021-9738 / 91 / 02 / 0694 / 10 \$ 2.00$

Volume 87, February 1991, 694-703 growth factors are released by platelets (PDGF, EGF/TGF- $\alpha$, TGF- $\beta 1$ ) and by activated macrophages (PDGF, TGF- $\beta 1$, bFGF, TGF- $\alpha$ ), cells that are required for normal wound repair, and appear to act in concert to influence critical activities in inflammation and in the wound healing process (1). As an example, PDGF is a potent chemoattractant for wound cells and is able to activate critical activities for wound healing within the cells as well (1-5). PDGF, EGF, bFGF, and TGF- $\beta 1$ also initiate activities characteristically associated with wound healing when infused into dead space chambers or into polyvinyl sponges implanted subcutaneously in rats (6-9); however, these findings may not be directly applicable to in vivo wound healing due to foreign body reactions and dead space artifacts. The abilities of PDGF and TGF- $\beta 1$ to directly accelerate wound healing were first shown in rat incisional wounds $(10$, 11). EGF and partially purified PDGF also appear to promote healing of porcine partial thickness wounds $(12,13)$. However, the full potential of growth factors to promote wound healing and the mechanisms by which growth factors effectively initiate the time-dependent activities essential to the wound healing process remain to be established. The effectiveness of individual growth factors in specific wound settings and the cascade of new gene transcription and resultant expression of additional mitogens and other proteins essential to the wound healing process is little understood. The experiments described in this manuscript were designed to test a unique wound model whose properties resembled the wound in human leg ulcers. The model was then used to test the influence of exogenously applied recombinant PDGF-BB, EGF, bFGF, and TGF- $\beta 1$ in promoting wound healing by measurement of rate of wound closure (reepithelialization), dimensions and estimated mass of new granulation tissue, and of proliferative activity and new protein and collagen synthesis in wound explants.

Specific and unique in vivo functions of each growth factor tested were observed and each growth factor was shown to markedly accelerate specific aspects of healing. The most surprising result was the unique ability of PDGF-BB to promote reepithelialization of wounds to the same extent as EGF and bFGF, which suggested an in vivo inductive effect of PDGFBB not previously observed that resulted in the enhancement of epithelial cell migration and proliferation. Only PDGF-BB and TGF- $\beta 1$ stimulated significant new granulation tissue in this in vivo model under conditions of study, suggesting an important use of these growth factors in healing full thickness dermal wounds.

\section{Methods}

The rabbit ear dermal ulcer model. Young adult New Zealand white rabbits, 3.0-3.5 kg (M \& K Rabbitry, Bentonville, AR) were anesthetized with ketamine $(60 \mathrm{mg} / \mathrm{kg})$ and xylazine $(5 \mathrm{mg} / \mathrm{kg})$, the ears immobilized in a plexiglass fabricated immobilizer (Washington University machine shop), and four 6-mm ulcers were made to the depth of bare 
cartilage under sterile conditions using microsurgical instruments, a 6-mm trephine, and a binocular microscope $(\times 10$; Carl Zeiss Inc., Thornwood, NY). Growth factors or vehicle alone were applied once only, and wounds were covered with an occlusive polyurethane film (Tegaderm; 3M, Minneapolis, MN). Neck collars (Canine Center, St. Louis, MO) were placed on rabbits for the duration of the experiment. At the time of killing, the ulcers were photographed, bisected, and fixed in $10 \%$ buffered formalin for routine histologic processing. After hematoxylin and eosin staining of 5- $\mu \mathrm{m}$ sections, the epithelial gap (EG), the granulation tissue gap (GTG), and the maximum height (MH) of granulation tissue at the advancing edges of the wound were measured using a calibrated lens micrometer (Fig. 1). Each wound was analyzed in a blinded fashion by two independent observers. Each observer's measurements were generally within $5 \%$ of the other, and were averaged for subsequent statistical analyses. Histological analyses of the ulcers immediately after wounding with the 6-mm trephine revealed an EG of $6.16 \pm 0.06 \mathrm{~mm}$ and a GTG of $5.86 \pm 0.08 \mathrm{~mm}$ (mean $\pm \mathrm{SE}, n=8$ ), corresponding to expectations and thus validating the surgical methods, wound bisection technique, and subsequent histological processing and analysis. The influx of new granulation tissue was calculated on specific days postwounding by subtracting each GTG from the day 0 GTG $(5.86 \mathrm{~mm})$. Approximate area and volume measurements for new granulation tissue were calculated, based on the assumptions that the wounds healed concentrically and did not contract. The area of NGT was calculated by subtracting the remaining wound area on the day of harvest (calculated from the GTG) from the day 0 wound area $\left(26.97 \mathrm{~mm}^{2}\right)$. India ink tattoos were placed at the wound periphery on day 0 to assess the degree of contraction during healing. After $7 \mathrm{~d}$, wound diameters were unchanged. Infected wounds $(<5 \%)$ or desiccated wounds $(<.5 \%)$ were excluded before measurements were made. Cultures of clinically noninfected wounds were repeatedly done and showed no growth of pathogens.

Application of growth factors to wounds. The growth factors were applied once at the time of surgery as a suspension with bovine collagen $(0.5 \mathrm{mg} /$ wound, Zyderm II; Collagen Corp., Palo Alto, CA $)(10,11)$, at the time of wounding. Growth factor and collagen control wounds were placed alternately on both ears. Occlusive dressings were used to prevent potential cross-contamination of adjacent wounds and to prevent wound desiccation. Preliminary experiments were done to exclude an influence of growth factors on adjacent control wounds, by comparison to control wounds placed on the opposite ear or on a different rabbit. The collagen vehicle had no effect on the measured parameters of ulcer healing when compared with wounds treated with saline or in the absence of treatment.

Growth factors. PDGF-BB, the recombinant homodimeric product of the human c-sis gene, was purified to homogeneity by immunoaffinity chromatography (gift of A. Thomason, Amgen Inc.) and had demonstrated equivalence to platelet-purified PDGF-AB (11). Recombinant natural sequence human EGF and recombinant natural sequence human bFGF were purified to homogeneity by column chromatography and were gifts of M. Nicolson (Amgen) and G. M. Fox (Amgen) (14), respectively. Recombinant TGF- $\beta 1$ was purified to homogeneity by

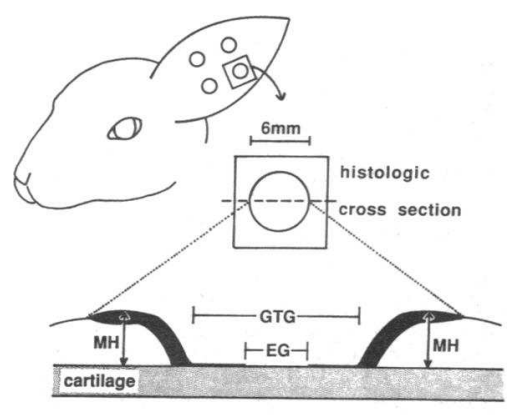

Figure 1. Diagram of the rabbit ear ulcer model. Quantitative measurements for granulation tissue formation and reepithelialization were obtained from histologic sections of bisected wounds using a calibrated lens micrometer. established methods (15) and was the gift of A. Ammann (Genentech Inc., South San Francisco, CA). All growth factors were free of detectable endotoxin.

Statistical analysis. Nonparametric and parametric statistical analyses were carried out using SAS software with the assistance of the Department of Biostatistics, Washington University.

Analysis of wound cellularity and explants. Cell suspensions were obtained under sterile conditions from 7-d-old wounds. Groups of four wounds were pooled after excising the entire original 6-mm biopsy sites with a trephine and placing them in a tissue culture dish containing Dulbecco's modified essential media and penicillin/streptomycin $(100 \mathrm{U} / \mathrm{ml}$ per $100 \mu \mathrm{g} / \mathrm{ml})$. Wounds were compressed between two sterile glass slides until a cell suspension was obtained. Cells were washed once, and counted using a hemacytometer and red cell lysing agent (American Scientific Products Div., American Hospital Supply Corp., McGraw Park, IL). Cells were suspended in serum-free Dulbecco's modified essential media-Ham's F12 (1/1 vol/vol) (11) and were plated into 12 wells of 96 -well microtiter plates (one wound equivalent per each three wells). Cultures were incubated with $10 \mu \mathrm{Ci} / \mathrm{ml}$ of one of the following tritiated reagents (all from New England Nuclear, Boston, MA): $\left[{ }^{3} \mathrm{H}\right]$ thymidine (sp act $85 \mathrm{Ci} / \mathrm{mmol}$ ), $\left[{ }^{3} \mathrm{H}\right]$ leucine (sp act $60 \mathrm{Ci} / \mathrm{mmol}$ ) in leucine-free media, and $\left[{ }^{3} \mathrm{H}\right]$ proline (sp act $35 \mathrm{Ci} /$ $\mathrm{mmol})$ in proline-free media. Ascorbic acid $(50 \mu \mathrm{g} / \mathrm{ml}$, Sigma Chemical Co., St. Louis, MO) and $\beta$-aminoproprinoitrile $(50 \mu \mathrm{g} / \mathrm{ml}$, Sigma) were added to cultures containing $\left[{ }^{3} \mathrm{H}\right]$ leucine or $\left[{ }^{3} \mathrm{H}\right]$ proline to optimize collagen synthesis and secretion, and to inhibit lysyloxidase-mediated collagen crosslinking and aggregation (16). Cultures were incubated for $5 \mathrm{~h}$ at $37^{\circ} \mathrm{C}$ in $5 \% \mathrm{CO}_{2}$ and were harvested on an automated cell harvester as described (11). In selected experiments, collagenase digestions were performed on cultures incubated with $\left[{ }^{3} \mathrm{H}\right]$ proline using established methods (17), to assess the amount of label specifically incorporated into collagen. Trichloroacetic acid-precipitable counts were counted in a scintillation counter and represent the disintegrations per minute per wound.

\section{Results}

Analysis of the dermal ulcer model. Both reepithelialization and formation of granulation tissue were first analyzed by histological means in both growth factor-treated and control wounds. Wound contracture as a variable was excluded (Fig. 2 $A-C)$. Because cartilage is avascular and the perichondrium was removed during surgery, new granulation tissue arose solely from the periphery of the wound. In preliminary experiments, the histological sections were analyzed on day 0 wounds (see Methods) and wounds were examined at 3, 5, 7, 10, and $14 \mathrm{~d}$ postwounding. The results were reproducible when analyzed by different observers. At day 3 , no reepithelialization had occurred; by days 10-14, all of the wounds were fully reepithelialized. However, differences in rates of healing could be readily appreciated at days 5 and 7 and these days were chosen for analysis to define differences in healing between treatment groups.

Effect of growth factors on healing rates. The effects of a single application of $5 \mu \mathrm{g}$ of recombinant-derived PDGF-BB, EGF, or bFGF were then analyzed relative to nontreated (vehicle alone) controls. The growth factors were applied once at the time of surgery. $5 \mu \mathrm{g}$ per wound $\left(7-31 \mathrm{pmol} / \mathrm{mm}^{2}\right)$ was chosen based upon the results of previous studies (7-12) and additional preliminary dose-response curves. $5 \mu \mathrm{g}$ PDGF-BB, EGF, or bFGF applied at the time of surgery was optimal for the observed results; doses up to $50 \mu \mathrm{g}$ per wound were neither more stimulatory nor inhibitory (data not shown), although on some occasions bFGF at higher doses appeared to be more 

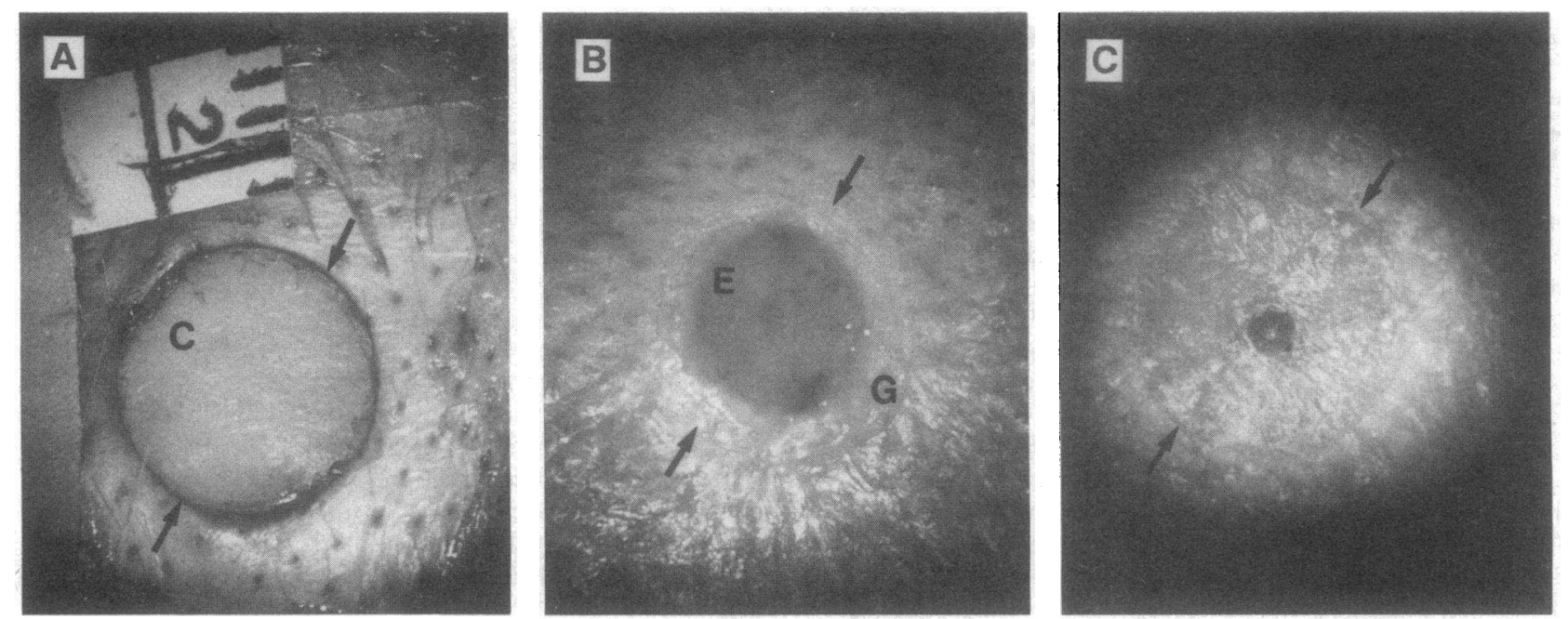

Figure 2. Photographs of the dermal wounds. $(A)$ Day 0 wound. (B) Partially healed day 7 wound. (C) Fully healed wound (day 14). The concentric healing and lack of contraction through day 7 are observed using the operating microscope (original magnification, 8). Contraction was quantified using India ink tattoos placed at the wound periphery and measured at day 7 (see Methods). Arrows demarcate the original wound borders, $6 \mathrm{~mm}$ in diameter. $C$, cartilage; $E$, new epithelium; $G$, new granulation tissue.

effective and induced some neovascularization. Doses lower than $1 \mu \mathrm{g}$ per wound did not demonstrate consistently reproducible biological activities.

At day 5 , reepithelialization was similar in treated wounds and in control wounds (global chi square analysis [data not shown]). However, the influx of new granulation tissue, calculated from the measured granulation tissue gap, was significantly increased $(229 \%)$ in PDGF-BB-treated wounds compared with controls $(1.01 \pm 0.14 \mathrm{~mm}$ vs. $0.44 \pm 0.14, n=19, P$ $=0.01$ ). Since the wounds healed concentrically (Fig. 2 ), the area of new granulation tissue could be estimated. In PDGFBB-treated wounds, the area was $8.50 \mathrm{~mm}^{2}$ after $5 \mathrm{~d}$ compared with $3.90 \mathrm{~mm}^{2}$ for control wounds ( $218 \%$ of control value); the estimated area of new granulation tissue in PDGF-BB-treated wounds after $5 \mathrm{~d}$ approached the area observed in control wounds after $7 \mathrm{~d}$, indicating nearly a 2-d acceleration of healing during the first week. PDGF-BB was far more effective than EGF or bFGF. After $5 \mathrm{~d}$, neither EGF- nor bFGF-treated wounds were significantly different from controls at the dose tested.

$7 \mathrm{~d}$ after treatment with single doses of $5 \mu \mathrm{g}$ of PDGF-BB, EGF, or bFGF, significant increases in degree and frequency of reepithelialization were found in each of the treated groups (Fig. 3). Twice as many growth factor-treated wounds were fully reepithelialized at day 7 when compared with controls $(P$ $=0.05$, global chi square analysis) and the median epithelial gap was nearly zero for growth factor-treated wounds. A 1.9mm gap remained in the control wounds. However, only PDGF-BB treatment stimulated additional new granulation tissue above control values at day 7 ; a $34 \%$ increase in the maximum height (Fig. 4) and a 53\% increase in the influx of granulation tissue was observed (Table I). The calculated approximate area of new granulation tissue of PDGF-BB-treated wounds was $149 \%$ that of control wounds at day 7 (Table I). A new tissue volume was estimated by multiplying these areas by the maximum height of the new granulation tissue (Fig. 4). PDGF-BB-treated wounds were $200 \%$ the estimated granulation tissue volume calculated for control wounds. The results thus established that PDGF-BB-, EGF-, and bFGF-treated wounds were strikingly different. PDGF-BB enhanced reepithelialization and new granulation tissue, while EGF and bFGF enhanced only reepithelialization although bFGF was less consistent. Whereas epithelial cells characteristically have EGF and FGF receptors and are mitogenically responsive to EGF and bFGF, PDGF receptors, and thus responsiveness to PDGF-BB, are largely limited to cells of mesenchymal origins. The positive epithelial response to PDGF-BB strongly suggests the induction of TGF- $\alpha$ or other keratinocyte-specific mitogens and thus an important inductive influence of granulation tissue on reepithelialization of wounds.

When $5 \mu \mathrm{g}$ TGF- $\beta 1$ was applied to wounds and analyzed,

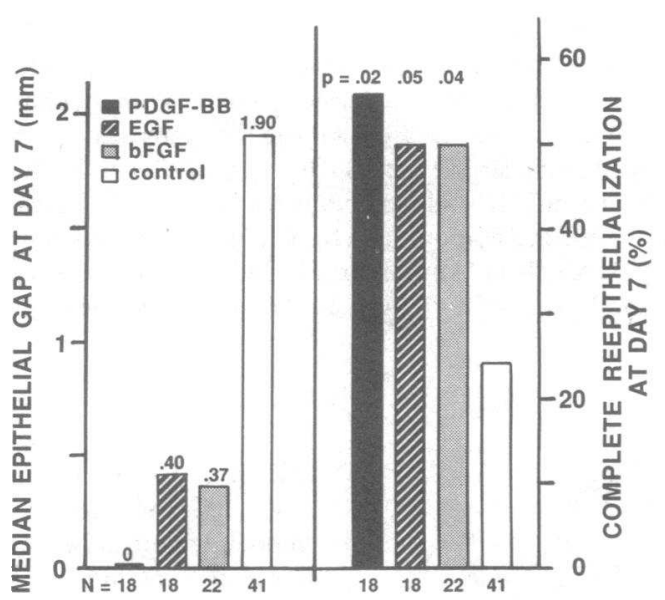

Figure 3. Measurement of reepithelialization in growth factor-treated wounds. The median epithelial gaps (EG) for PDGF-BB, EGF, bFGF, and controls at day 7 are presented, since the data were not normally distributed because some wounds had fully reepithelialized. At day 7 , the percentage of wounds fully reepithelialized is displayed. The frequency of complete reepithelialization for growth factor treated and control wounds was analyzed using the chi square test. 


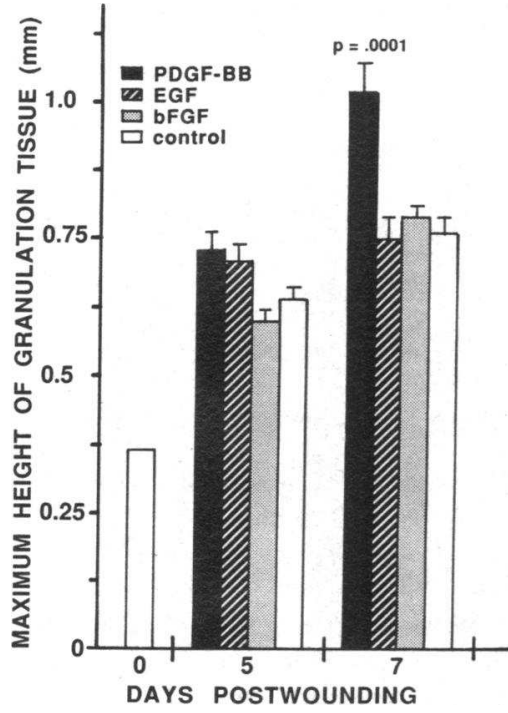

Figure 4. Measurement of the MH of new granulation tissue in growth factor-treated wounds. PDGF-BB treatment induced a significantly greater $\mathrm{MH}$ at day $7(P=0.0001$, unpaired two-tailed $t$ test, and $P=0.0007$ by nonparametric KruskalWallis test). Day 0 tissue height is $0.37 \mathrm{~mm}$.

significant increases in the height of new granulation tissue ( $163 \%$ of control) were observed. A lesser effect on the influx of new granulation tissue (129\% of control) and significant inhibition of reepithelialization ( $P=0.05$, chi square analysis), also was found (Table II). Because TGF- $\beta 1$ was highly effective in stimulating granulation tissue in a rat linear incisional model, the lesser effect on formation of granulation tissue was unexpected (6). Additional doses of TGF- $\beta 1$ were then analyzed. Remarkably, a more potent enhancement of granulation tissue and loss of inhibition of reepithelialization was observed when $1 \mu \mathrm{g}$ TGF- $\beta 1\left(1.5 \mathrm{pmol} / \mathrm{mm}^{2}\right)$ per wound was tested (Table II). At $1 \mu \mathrm{g}$ TGF- $\beta 1$ per wound, maximum height was $157 \%$ of controls, influx of new granulation tissue was $189 \%$ of controls, and the calculated area of new granulation tissue was 15.09 $\mathrm{mm}^{2}, 173 \%$ of controls $(P=0.001)$. TGF- $\beta 1$ thus demonstrated a bimodal dose-response curve in this model, with optimal results obtained at $1 \mu \mathrm{g}$ per wound. TGF- $\beta 1$ did not enhance reepithelialization at lower doses (Table II).

Histologic analyses of the wounds at day 7. Marked increases in fibroblast influx and matrix deposition were apparent in PDGF-BB- and TGF- $\beta 1$-treated wounds compared with controls (Fig. $5 a$ ). Increased wound macrophage influx was also observed at days 3 and 5 in PDGF-BB- or TGF- $\beta 1$ treated wounds. EGF-treated wounds appeared similar to controls, while bFGF-treated wounds tended to contain an increased cellular influx, but lacked the increased granulation tissue and deposition of matrix so prominent in PDGF-BB- or TGF- $\beta 1$-treated wounds (Fig. 5, $b$ and $c$ ). PDGF-BB-, EGF-, and bFGF-treated wounds had thickened epithelium at the wound margins compared with controls. Angiogenesis was present in all wounds at levels necessary to support the induced granulation tissue; bFGF-treated wounds appeared to have increased neovessel formation (Fig. $5 c$ ); this increase was not quantified.

Analysis of wound explants. PDGF-BB- and EGF-treated wounds were selected for further study since both growth factors had significantly different effects on the healing wounds. Due to the lack of wound contraction, it was possible to excise all the newly formed tissue at $7 \mathrm{~d}$ within the $6-\mathrm{mm}$ wound. This newly formed tissue then was analyzed to quantitate wound cellularity and to estimate rates of DNA, protein, and collagen synthesis in the wound cells in short term explant cultures. In comparison to control wounds, PDGF-BB-treated wounds contained $270 \%$ and EGF-treated wounds contained $190 \%$ more cells (Fig. 6). Hematoxylin and eosin stained preparations from each experiment established that the increase in cells in PDGF-BB-treated wounds was predominantly fibroblastic, while EGF-treated wounds appeared to contain more epithelial cells. The number of other wound cells, such as macrophages and endothelial cells, was difficult to assess using routine staining techniques and thus was not quantitated.

Cellular proliferation as estimated by $\left[{ }^{3} \mathrm{H}\right]$ thymidine incorporation in PDGF-BB-treated wounds was $345 \pm 87 \%$ of control wounds, while EGF-treated wounds were only slightly above control (Fig. 6). Total protein synthesis (cells and media) as estimated by $\left[{ }^{14} \mathrm{C}\right]$ leucine incorporation from PDGF-BBtreated wounds was $473 \%$ of controls; estimated protein synthesis in cells from EGF-treated wounds was only slightly above control wound cell values (132\%). Since collagen represents a significant percentage of total protein synthesis in fibroblasts $(18,19)$, incorporation of radiolabeled proline was assessed also and was found to parallel the results obtained with radiolabeled leucine. Collagenase-sensitive protein was measured in some experiments; collagenase-sensitive protein represented $\sim 75 \%$ of the total proline incorporation in the explant cultures for both PDGF-BB-treated and control cells, and 25\% of the total proline incorporated into EGF-treated wound cells, suggesting a greater total synthesis of new collagen in PDGFBB-treated wounds. Although bFGF- and TGF- $\beta 1$-treated wounds were not analyzed in these experiments, bFGF and TGF- $\beta 1$ would be expected to behave similarly to EGF and PDGF-BB, respectively.

\section{Discussion}

The results in this work have demonstrated the unique capacity for significant augmentation of wound healing by a single ap-

Table I. Formation of New Granulation Tissue in the Rabbit Ear Ulcer Model after 7 Days*

\begin{tabular}{lccc}
\hline $\begin{array}{c}\text { Growth } \\
\text { factor }^{*}\end{array}$ & $\begin{array}{c}\text { New granulation } \\
\text { tissue influx }\end{array}$ & $\begin{array}{c}\text { New granulation } \\
\text { tissue area }\end{array}$ & $\begin{array}{c}\text { New granulation } \\
\text { tissue volume }\end{array}$ \\
\hline & $m m$ & $\mathrm{~mm}^{2}$ & $\mathrm{~mm}^{3}$ \\
PDGF-BB & $1.81 \pm 0.17(153)^{8}$ & $14.01 \pm 1.06(149)$ & $14.29 \pm 1.08(200)$ \\
EGF & $1.21 \pm 0.17$ & $9.66 \pm 1.22$ & $7.25 \pm 0.91$ \\
bFGF & $1.20 \pm 0.13$ & $9.64 \pm 0.96$ & $7.62 \pm 0.76$ \\
Control & $1.18 \pm 0.12$ & $9.40 \pm 0.83$ & $7.14 \pm 0.64$ \\
$P$ value & 0.004 & 0.005 & 0.0002
\end{tabular}

* Calculations of granulation tissue influx and an approximation of area and volume were made from the measurements obtained as described in Fig. 1. The mean \pm SE ( $n$ as in Fig. 3 ) is presented. On day 0 (day of surgery), the measured granulation tissue gap was 5.86 $\mathrm{mm}$ and the area was $(5.86 / 2)^{2} \pi=26.97 \mathrm{~mm}^{2}$. Parameters of healing were calculated as follows: new granulation tissue influx $=5.86 \mathrm{~mm}$ minus GTG for each biopsy; new granulation tissue area = area of wound at day 0 minus area of wound at day 7 ; new granulation tissue volume $=$ area $\times$ MH (from Fig. 4)

$\ddagger 5 \mu \mathrm{g}$ of each growth factor was applied to each biopsy at the time of surgery.

"Two-tailed unpaired $t$ test, PDGF-BB vs. control.

${ }^{8}$ Numbers in parentheses indicate the PDGF-BB-treated values as a percentage of control. 


\begin{tabular}{rccccc}
\hline & Maximum height* & $\begin{array}{c}\text { New granulation } \\
\text { tissue influx }\end{array}$ & $\begin{array}{c}\text { Median } \\
\text { epithelial gap }\end{array}$ & $\begin{array}{c}\text { Frequency of complete } \\
\text { reepithelialization }\end{array}$ \\
\hline Control & $N$ & $m m$ & $m m$ & $m m$ \\
TGF- $\beta 1$ & 54 & $0.56 \pm 0.01$ & $1.04 \pm 0.15$ & 1.71 & 26 \\
$0.2 \mu \mathrm{g}$ & 18 & $0.72 \pm 0.03(128)^{\ddagger}$ & $1.77 \pm 0.20(170)$ & & \\
$1.0 \mu \mathrm{g}$ & 27 & $0.88 \pm 0.03(157)^{\ddagger}$ & $1.97 \pm 0.23(189)^{5}$ & 2.62 & 33 \\
$5.0 \mu \mathrm{g}$ & 15 & $0.91 \pm 0.04(163)^{\ddagger}$ & $1.34 \pm 0.16(129)$ & 2.95 & 0 \\
\end{tabular}

${ }^{*}$ Mean \pm SE. Numbers in parentheses represent the percentage of control wound values. ${ }^{\ddagger} P=0.001$, two-tailed unpaired Student's $t$ test. ${ }^{\S} P$ $=0.01$, two-tailed unpaired Student's $t$ test. " $P=0.05$, chi square analysis.

plication of PDGF-BB, EGF, bFGF, or TGF- $\beta 1$. PDGF-BB significantly accelerated reepithelialization and formation of granulation tissue, while EGF and bFGF promoted reepithelialization but not new granulation tissue significantly above the levels found in control, nontreated wounds. The effect of bFGF was less consistent, however, and increased new granulation tissue and neovascularization was seen in some wounds. TGF$\beta 1$ was a potent inducer of new granulation tissue formation. However, at its optimal dose ( $1 \mu \mathrm{g}$ per wound), no stimulation of reepithelialization was observed, and reepithelialization was inhibited at higher concentrations, consistent with TGF- $\beta 1$ 's known inhibitory activities on growth of cultured keratinocytes (20). In response to EGF- and bFGF-accelerated epithelialization, the epithelium formed a thin sheet over the cartilage, a direct analogy to clinical full thickness dermal wounds in which new epithelium forms over a poor supporting bed of granulation tissue; the new tissue is friable and reulcerates with high frequency. However, the results suggest that EGF and bFGF may be very effective in accelerating repair of partial thickness clinical wounds, such as donor graft sites (21), where enhanced epithelialization, and not granulation tissue formation, is required.

PDGF has no direct biologic activity on keratinocytes in vitro, since these cells appear to lack PDGF receptors (1). In this ulcer model, however, the striking promotion of reepithelialization induced by PDGF-BB requires that PDGF-BB act through an inductive effect, presumably secondary to its potent influence on cell recruitment $(2,3)$ and its inductive effect on cells entering new granulation tissue, perhaps stimulating new synthesis of TGF- $\alpha$ or keratinocyte growth factor. The macrophage is capable of synthesizing TGF- $\alpha$ and activation by PDGF has been documented (22). Thus, the influx of the macrophage into 3-5-d-old wounds may be critical to the reepithelialization of PDGF-treated wounds. These experiments thus highlight the critical inductive interactions between the underlying supporting layer of granulation tissue and the overlying epithelium and have provided a model in which these effects may be analyzed directly. TGF- $\beta 1$ was at least as effective as PDGF-BB in inducing granulation tissue; the inhibition of reepithelialization observed with TGF- $\beta 1$ in this model may complicate its use in chronic dermal wounds in man, in which reepithelialization is an important component of healing.

PDGF-BB is a potent activator of TGF- $\beta 1$ gene expression in macrophages and fibroblasts in vitro $(22,23)$. In addition, PDGF-BB induces PDGF A-chain gene expression in fibroblasts (24; and Pierce, G. F., B. D. Tong, V. R. Masakowski, J.
Lingelbach, C. Hsu, N. R. Siegal, and T. F. Deuel; submitted for publication), suggesting the potential for exogenous PDGFBB to initiate a positive autocrine feedback loop and cascade effect on endogenous growth factor synthesis within wounds. PDGF-BB directly enhanced macrophage and fibroblast influx in the linear incision model $(11,23)$ consistent with its striking chemotactic potential in vitro $(2,3,11)$. PDGF also activates inflammatory cells in vitro $(4,5)$ and PDGF-BB increased the in situ expression of TGF- $\beta$ in wound cells but not surrounding cells as assessed by immunohistochemistry (23). PDGF-BB in vitro fails to activate the procollagen type I gene (25), although it does stimulate fibronectin synthesis (26); some of its influence in the induction of granulation tissue and specifically on the synthesis of procollagen type I likely is indirect, perhaps mediated through capacity of PDGF-BB to induce TGF- $\beta 1$ $(22,23)$.

TGF- $\beta 1$ subsequently also has been shown to be a potent chemoattractant and growth factor $(23,27,28)$; it also induces growth factor expression (i.e., TGF- $\beta$, PDGF) and directly stimulates extracellular matrix synthesis (i.e., procollagen type I) in cultured fibroblasts $(27,29,30)$. These in vitro activities are entirely consistent with TGF- $\beta 1$ 's known in vivo potent dermoplastic effects, in incisional $(10,22,23)$ and excisional models of wound repair (this report).

The biologic activity of purified bFGF toward keratinocytes in vitro was only recently reported (31). However, accelerated dermal reepithelialization in vivo by bFGF has not been previously demonstrated. Since keratinocytes have specific receptors for bFGF and respond to bFGF mitogenically in vitro, our findings suggest a new and direct in vivo activity for bFGF. In vitro, bFGF is also a potent chemotactic and mitogenic agent for fibroblasts and endothelial cells and stimulates new vessel formation $(32,33)$. Although some increased capillary budding was observed, bFGF did not significantly increase new granulation tissue or neovascularization at the doses used in this model, but it did recruit fibroblast-like cells into wounds as demonstrated histologically. Additional work is needed to reconcile these results, perhaps using different vehicles to insure appropriate delivery of bFGF to these wounds. Thus, the minimal effects of bFGF on new granulation tissue formation and neovascularization may have been related to stability of the natural sequence growth factor (14), a requirement for heparin stabilization (33), or its release kinetics from the collagen vehicle. Repeated applications of EGF and the related polypeptides TGF- $\alpha$ and vaccinia growth factor were previously shown to augment healing of partial thickness wounds in pigs and rabbits 

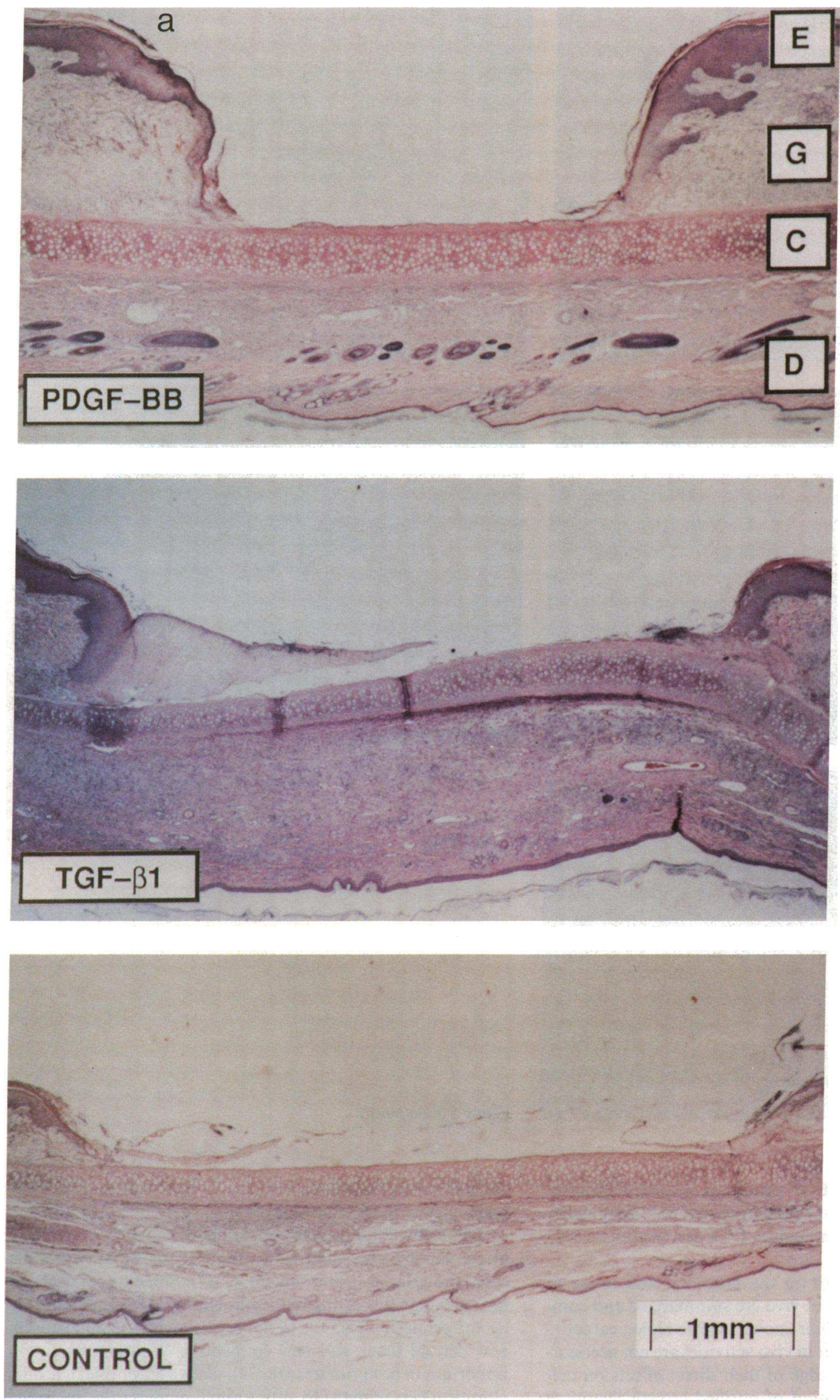

Figure 5. Histologic analysis of growth factortreated ulcers.

Representative bisections from PDGF-BB, TGF- $\beta 1$, EGF, bFGF, and control wounds were obtained as described in Fig. 1. $a$

(original magnification, 16) shows the entire 6-mm biopsy site. Note the increased influx of granulation tissue into the PDGF-BB- and TGF- $\beta 1$ treated wounds. EGF- and bFGF-treated wounds were similar to controls. $E$, epidermis; $G$, new granulation tissue; $C$, cartilage; $D$, unwounded dermis. $b$ (original magnification, 80) shows the leading edge of new granulation tissue in the wound. Note the increased fibroblastic influx and matrix synthesis in PDGF$\mathrm{BB}$ - and TGF- $\beta 1$-treated wounds, compared with EGF, bFGF, or control wounds. $c$ (original magnification, 320) shows the fibroblastic and keratinocyte influx at the leading edge of new granulation tissues in the wounds. EGF-treated wounds were histologically similar to controls, while bFGF-treated wounds showed some increased cellular influx and neovascularization. EGF, bFGF, and PDGF-BB similarly enhanced reepithelialization rates. 5 $\mu \mathrm{g}$ of PDGF-BB, EGF, or bFGF, or $1 \mu \mathrm{g}$ TGF- $\beta 1$ was applied to wounds. 

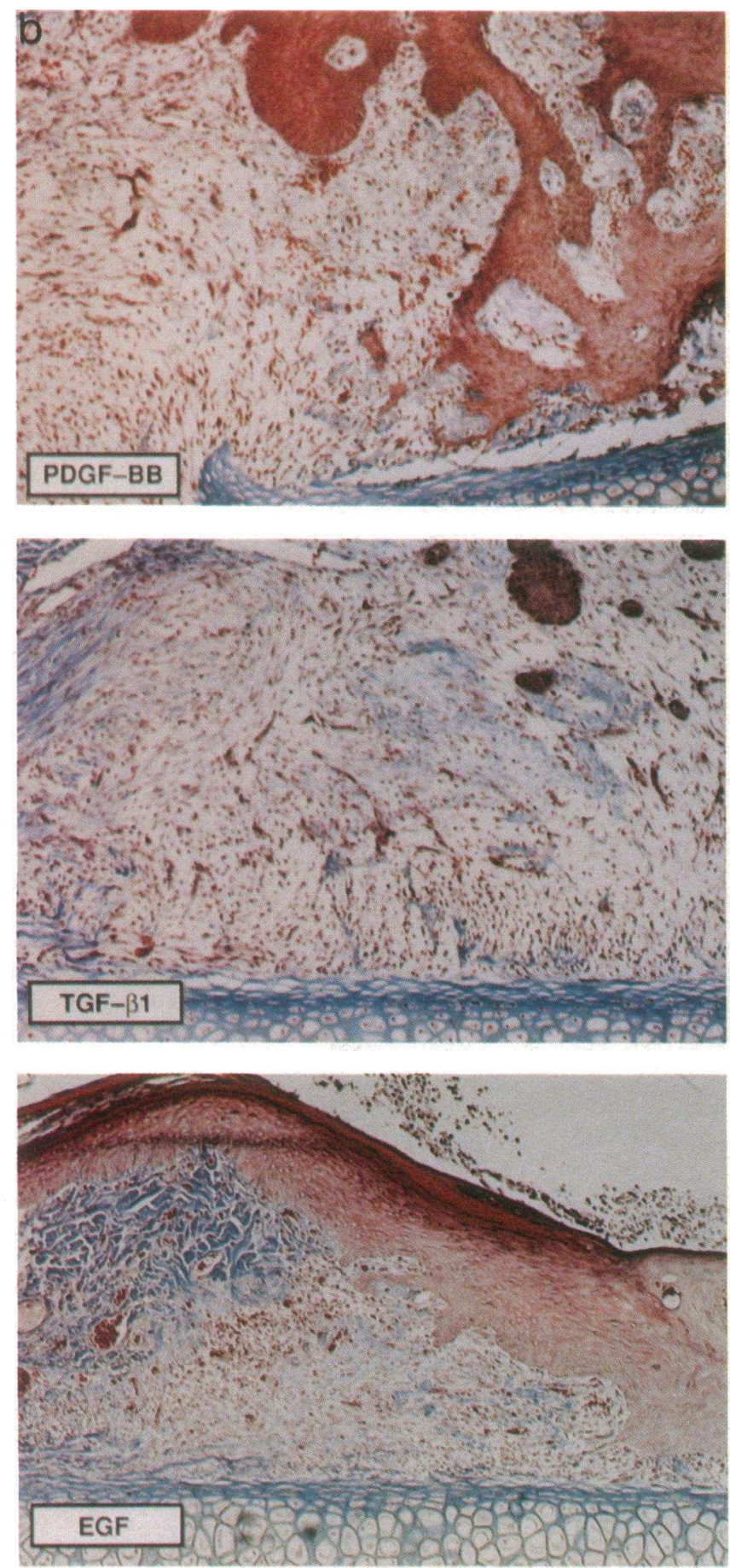

$(12,34,35)$. In this work, EGF promoted reepithelialization with a single application and thus this model may be a highly appropriate model to further analyze EGF as a wound healing agent.

The results of this work on the potential and range of growth promoting activities in vivo are summarized and compared, and contrasted with their known in vitro biological activities in Table III. Clearly their in vivo activities are not necessarily predicted from a knowledge of their direct effects on cultured cells. In vivo application of purified growth factors at optimal concentrations is of crucial importance; suboptimal
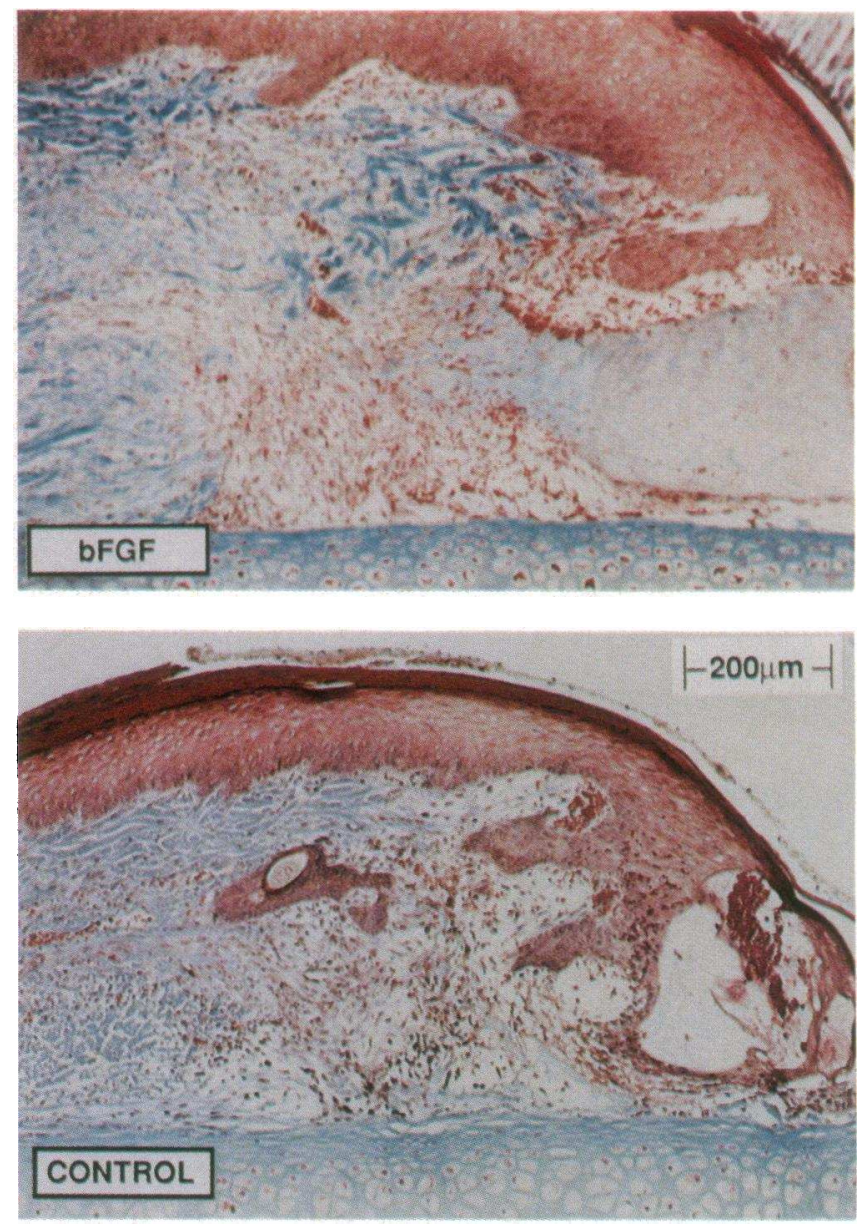

Figure 5 (Continued)

doses alone or in combination, or use of partially purified preparations may mask significant biologic activities (13).

Clinically, the largest category of nonhealing wounds are leg ulcers, largely associated with venous stasis, small vessel disease, and arterial insufficiency $(36,37)$. Since these ulcers are full thickness (involving both epithelium and dermis), healing occurs primarily from the periphery by an interaction between new dermal tissue and new epithelium. Wound contraction, important in nonprimates $(38,39)$, plays a lesser role in healing chronic ulcers in man $(18,40)$. Animal models using incisional wounds, in which generation of wound strength by new colla- 

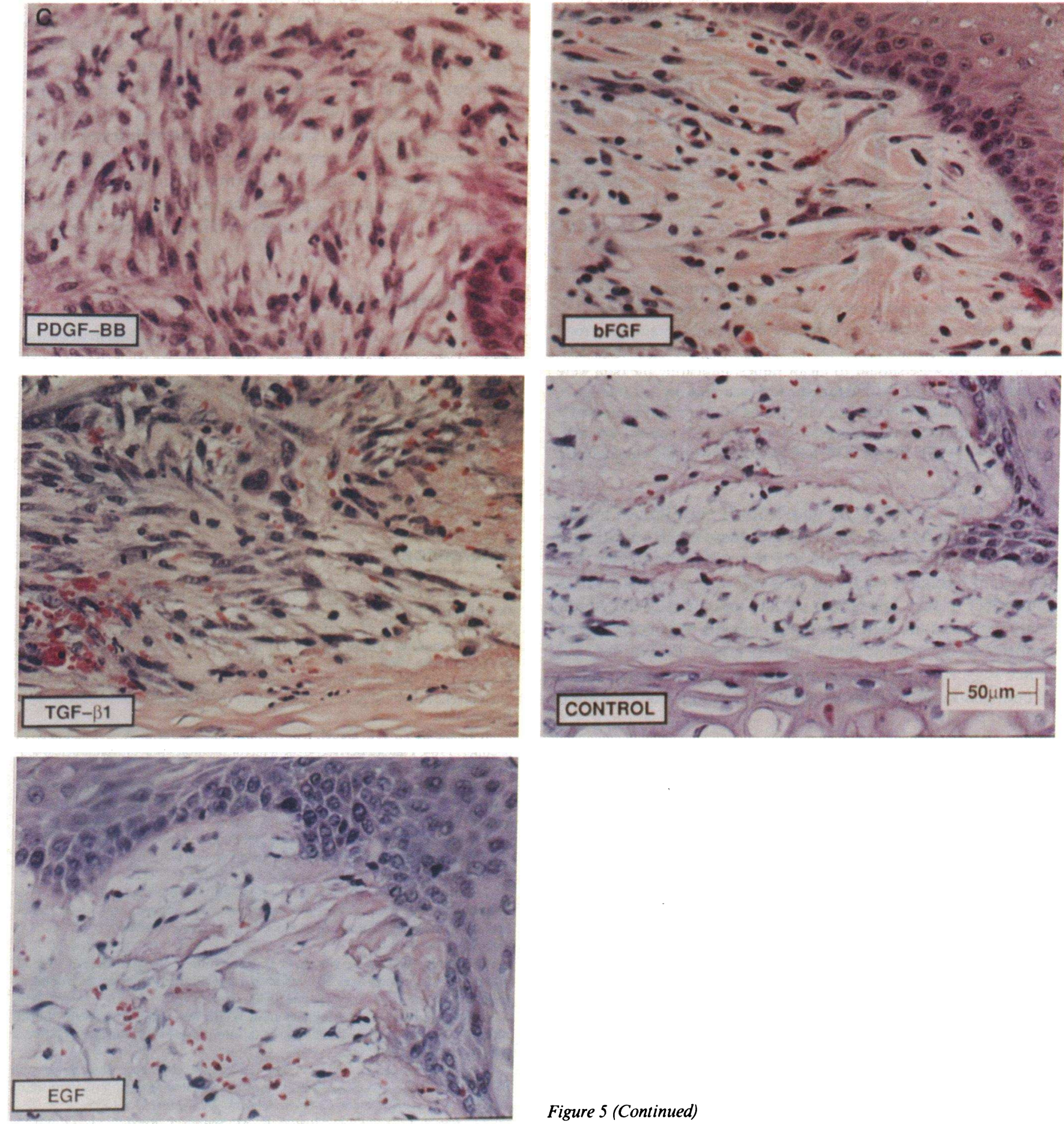

Figure 5 (Continued)

gen synthesis is the major determinant of healing $(19,41)$, and partial thickness wounds, in which reepithelialization arises from the underlying epithelial elements retained in the dermis (42), provide little information on the interaction between reepithelialization and formation of granulation tissue, both of which may be rate-limiting in the healing of dermal ulcers. The dermal ulcer model provides significant advantages over previously published wound healing models because wound contraction is minimized and because both new granulation and epithelial tissues migrate into the wound from the periph-

ery, permitting quantitation of both processes. The dermal ulcer model is similar to full thickness clinical ulcers, in that both an influx of granulation tissue and reepithelialization are essential for adequate repair. However, unlike most ulcers, the rabbit wounds have an avascular cartilage base, preventing new granulation tissue ingrowth from the wound base. The cartilage base did not appear to influence repair processes at the time points analyzed; in wounds followed for a month or more some evidence of cartilage remodeling was observed (unpublished observations). 


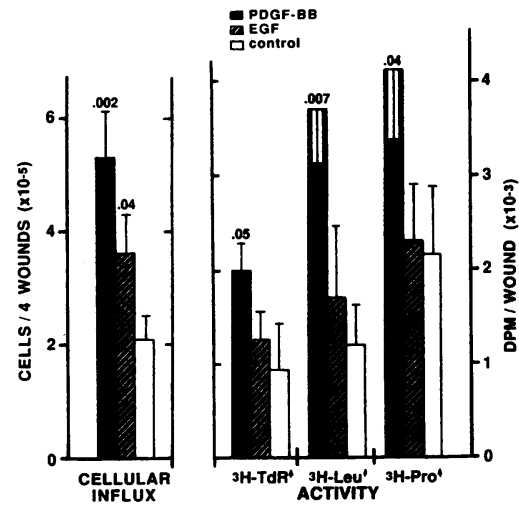

Figure 6. Analysis of wound cellularity and wound explants. A single cell suspension was obtained from four pooled wounds, cells were counted, then placed into media containing $\left[{ }^{3} \mathrm{H}\right]-$ thymidine, $\left[{ }^{3} \mathrm{H}\right]$ leucine, or $\left[{ }^{3} \mathrm{H}\right]$ proline as described in Methods. Collagenase-sensitive $\left[{ }^{3} \mathrm{H}\right]$ proline incorporation was

assessed in some experiments to determine the degree of label incorporation specifically into collagen. The means ( \pm standard errors) of four to nine experiments for each variable are presented. Medians for all data sets were similar to mean values, indicating the data were normally distributed. A one-tailed $t$ test was used to test the hypothesis that PDGF-BB or EGF treated wounds had increased cellularity and metabolic processes compared with control wounds. A total of 44 PDGF-BB, 44 EGF, and 50 control wounds was analyzed.

PDGF-BB, bFGF, EGF, and TGF- $\beta 1$ each induce unique responses in enhancing the healing of these ulcers. Analysis of these growth factors in this model has suggested further their important inductive effects on cells entering the wound. A cascade effect in turn appears to initiate and amplify the wound healing process through stimulation of cells not necessarily responsive to the growth factor initially added. Preliminary evidence suggesting the wound macrophage as a principal source of endogenous growth factor activities was reported by Rappo-

Table III. Summary of the Effects of a Single Application of Growth Factors in the Rabbit Dermal Ulcer Model*

\begin{tabular}{|c|c|c|c|c|}
\hline \multirow[b]{2}{*}{ Biological activity } & \multirow[b]{2}{*}{ PDGF-BB } & \multicolumn{2}{|c|}{ Growth factor } & \multirow[b]{2}{*}{ TGF- $\beta 1$} \\
\hline & & EGF & bFGF & \\
\hline \multicolumn{5}{|l|}{ In vivo } \\
\hline Reepithelialization & + & + & + & $-/ 0$ \\
\hline Macrophage influx & + & 0 & 0 & 0 \\
\hline Fibroblast influx & + & 0 & $0 /+$ & + \\
\hline $\begin{array}{l}\text { Granulation tissue and } \\
\text { collagen synthesis }\end{array}$ & + & 0 & $0 /+$ & + \\
\hline \multicolumn{5}{|l|}{ In vitro } \\
\hline Keratinocyte growth ${ }^{\ddagger}$ & 0 & + & + & - \\
\hline Monocyte chemotaxis 8 & + & 0 & 0 & + \\
\hline Fibroblast chemotaxis ${ }^{8}$ & + & + & + & + \\
\hline Collagen type I synthesis" & 0 & 0 & 0 & + \\
\hline Growth factor synthesis' & + & + & + & + \\
\hline
\end{tabular}

* Growth factors $(5 \mu \mathrm{g})$ were applied once at the time of surgery in a collagen vehicle; wounds were evaluated $7 \mathrm{~d}$ later. + , activity present; 0 , activity not present; - , inhibitory activity; $-/ 0$ or $0 /+$, an effect has been reported, may depend upon the experimental conditions and model used.

${ }^{\ddagger}$ References $1,20,31$.

References 1, 2, 3, 23, 27, 28, 32 .

"References $25,26,30$. Only TGF- $\beta 1$ has been shown to stimulate collagen type I synthesis directly (25).

' References 22-24, 27, 28, 29, 30, 43, 44. lee and co-workers (43), and our in vitro and in vivo data in linear incisions demonstrate the importance of endogenous growth factor production in PDGF-BB or TGF- $\beta 1$ wound macrophages and fibroblasts $(22,23)$. It will be of interest to use the rabbit ear dermal ulcer model to analyze the induction of endogenous growth factors and activities such as angiogenesis, and extracellular matrix formation and the abilities of exogenous growth factor therapy to reverse impaired dermal healing induced by drugs, radiation, or ischemia. This approach is presently underway and may permit the identification of specific therapeutic approaches for states of clinically deficient tissue repair.

\section{Acknowledgments}

We thank J. Reed and J. Lingelbach for excellent technical assistance and C. Arfkyn for statistical advice. We appreciate the histologic and graphics assistance of M. Kopinski and J. Heuston, respectively. We thank A. Thomason, A. Ammann, G. M. Fox, and M. Nicolson for purified growth factors and ongoing interest, and R. Diegelmann for advice in establishing the collagen assay.

This study was supported by National Institutes of Health grants HL-14147, HL-31 102, and CA-49712, and by grants from Amgen Inc. and Genentech Inc.

\section{References}

1. Deuel, T. F. 1987. Polypeptide growth factors: roles in normal and abnormal cell growth. Annu. Rev. Cell. Biol. 3:443-492.

2. Deuel, T. F., R. M. Senior, J. S. Huang and G. L. Griffin. 1982. Chemotaxis of monocytes and neutrophils to platelet-derived growth factor. J. Clin. Invest. 69:1046-1049.

3. Senior, R. M., G. L. Griffin, J. S. Huang, D. A. Walz, and T. F. Deuel. 1983. Chemotactic activity of platelet alpha granule proteins for fibroblasts. J. Cell Biol. 96:382-385.

4. Tzeng, D. Y., T. F. Deuel, J. S. Huang, R. M. Senior, L. A. Boxer, and R. L. Baehner. 1984. Platelet-derived growth factor promotes polymorphonuclear leukocyte activation. Blood. 64:1123-1128.

5. Tzeng, D. Y., T. F. Deuel, J. S. Huang, and R. L. Baehner. 1985. Plateletderived growth factor promotes human peripheral monocyte activation. Blood. 66:179-183.

6. Grotendorst, G. R., G. R. Martin, D. Pancev, J. Sodek, and A. K. Harvey. 1985. Stimulation of granulation tissue formation by platelet-derived growth factor in normal and diabetic rats. J. Clin. Invest. 76:2323-2329.

7. Davidson, J. M., M. Klagsbrun, K. E. Hill, A. Buckley, R. Sullivan, P. S. Brewer, and S. C. Woodward. 1985. Accelerated wound repair, cell proliferation, and collagen accumulation are produced by a cartilage-derived growth factor. $J$. Cell Biol. 100:1219-1227.

8. Buckley, A., J. M. Davidson, C. D. Kameroth, T. B. Wolt, and S. C. Woodward. 1985. Sustained release of epidermal growth factor accelerates wound repair. Proc. Natl. Acad. Sci. USA. 82:7340-7344.

9. Sprugel, K. H., J. M. McPherson, A. W. Clowes, and R. Ross. 1987. Effects of growth factors in vivo. I. Cell ingrowth into porous subcutaneous chambers. Am. J. Pathol 129:601-613.

10. Mustoe, T. A., G. F. Pierce, A. Thomason, P. Gramates, M. B. Sporn, and T. F. Deuel. 1987. Accelerated healing of incisional wounds in rats induced by transforming growth factor- $\beta$. Science (Wash. DC). 234:1333-1335.

11. Pierce, G. F., T. A. Mustoe, R. M. Senior, J. Reed, G. L. Griffin, A. Thomason, and T. F. Deuel. 1988. In vivo incisional wound healing augmented by platelet-derived growth factor and recombinant c-sis gene homodimeric proteins. J. Exp. Med. 167:974-987.

12. Brown, G. L., L. Curtsinger III, J. R. Brightwell, D. M. Ackerman, G. R. Tobin, H. C. Polk, Jr., C. George-Nascimento, P. Valenzuela, and G. S. Schultz 1986. Enhancement of epidermal regeneration by biosynthetic epidermal growth factor. J. Exp. Med. 163:1319-1324.

13. Lynch, S. E., J. C. Nixon, R. B. Colvin, and H. N. Antoniades. 1987. Role of platelet-derived growth factor in wound healing: synergistic effects with other growth factors. Proc. Natl. Acad. Sci. USA. 84:7696-7700.

14. Fox, G. M., S. G. Schiffer, M. F. Rohde, L. B. Tsai, A. R. Banks, and T. Arakawa. 1988. Production, biological activity, and structure of recombinant basic fibroblast growth factor and an analog with cysteine replaced by serine. $J$. Biol. Chem. 263:18452-18458.

15. Shalaby, M. R., and A. J. Ammann. 1988. Suppression of immune cell 
function in vitro by recombinant human transforming growth factor- $\beta$. Cell. Immunol. 112:343-350.

16. Jimenez, S. A., W. McArthur, and J. Rosenbloom. 1979. Inhibition of collagen synthesis by mononuclear cell supernates. J. Exp. Med. 150:1421-1431.

17. Peterkofsky, B., and R. Diegelmann. 1971. Use of a mixture of proteinasefree collagenase for the specific assay of radioactive collagen in the presence of other proteins. Biochemistry. 10:988-994. phia.

18. Peacock, E. E. 1984. Wound Repair. 3rd ed. W. B. Saunders Co., Philadel-

19. Dunphy, J. E., and K. N. Udupa. 1955. Chemical and histochemical sequences in the normal healing of wounds. N. Engl. J. Med. 253:847-851.

20. Coffey, R. J., Jr., N. J. Sipes, C. C. Bascom, R. Graves-Deal, C. Y. Pennington, B. E. Weissman, and H. L. Moses. 1988. Growth modulation of mouse keratinocytes by transforming growth factors. Cancer Res. 48:1596-1602.

21. Brown, G. L., L. B. Nanney, J. Griffen, A. B. Cramer, J. M. Yancey, L. J. Curtsinger III, L. Holtzin, G. S. Schultz, M. J. Jurkiewicz, and J. B. Lynch. 1989. Enhancement of wound healing by topical treatment with epidermal growth factor. N. Engl. J. Med. 321:76-79.

22. Pierce, G. F., T. A. Mustoe, J. Lingelbach, V. R. Masakowski, P. Gramates, and T. F. Deuel. 1989. Transforming growth factor $\beta$ reverses the glucocorticoid-induced wound healing deficit in rats. Proc. Natl. Acad. Sci. USA. 86:2229-2233.

23. Pierce, G. F., T. A. Mustoe, J. Lingelbach, V. R. Masakowski, G. Griffin R. M. Senior, and T. F. Deuel. 1989. Platelet-derived growth factor and transforming growth factor $-\beta$ enhance tissue repair activities by unique mechanisms. J. Cell Biol. 109:429-440.

24. Paulsson, Y., A. Hammacher, C.-H. Heldin, and B. Westermark. 1987 Possible positive autocrine feedback in the prereplicative phase of human fibroblasts. Nature (Lond.). 328:715-717.

25. Rossi, P., G. Karsenty, A. B. Roberts, N. S. Ruche, M. B. Sporn, and B. de Crombrugghe. 1988. A nuclear factor 1 binding site mediates the transcriptional activation of a type 1 collagen promoter by transforming growth factor- $\beta$. Cell. 52:405-414.

26. Blatti, S. P., D. N. Foster, G. Ranganathan, H. L. Moses, and M. J. Getz. 1988. Induction of fibronectin gene transcription and mRNA is a primary response to growth factor stimulation of AKR-2B cells. Proc. Natl. Acad. Sci. USA. 85:1119-1123.

27. Wahl, S. M., N. McCartrey-Francis, and S. E. Mergenhagen. 1989. Inflammatory and immunomodulatory roles of TGF- $\beta$. Immunol. Today. 10:258-261.

28. Postlethwaite, A. E., J. Keski-Oja, H. L. Moses, and A. H. Kang. 1987.
Stimulation of the chemotactic migration of human fibroblasts by transforming growth factor- $\beta$. J. Exp. Med. 165:251-256.

29. Van Obberghen-Schilling, E., N. S. Roche, K. L. Flanders, M. B. Sporn, and A. B. Roberts. 1988. Transforming growth factor $\beta 1$ positively regulates its own expression in normal and transformed cells. $J$. Biol. Chem. 263:7741-7746.

30. Keski-Oja, J., R. Raghow, M. Sawdey, D. J. Loskutoff, A. E. Postlethwaite, A. H. Kang, and H. L. Moses. 1988. Regulation of mRNAs for type-1 plasminogen activator inhibitor, fibronectin and type I procollagen by transforming growth factor- $\beta$. J. Biol. Chem. 263:3111-3115.

31. O'Keefe, E. J., M. L. Chiu, and R. E. Payne. 1988. Stimulation of growth of keratinocytes by basic fibroblast growth factor. J. Invest. Dermatol. 90:767769.

32. Buckley, A., R. M. Senior, G. L. Griffin, M. Klagsbrun, S. C. Woodward, and J. M. Davidson. 1989. Growth factors direct cell movement in fibroblasts from rat granulation tissue and human skin. J. Cell. Physiol. 138:70-78.

33. Rifkin, D. B., and D. Moscatelli. 1989. Recent developments in the cell biology of basic fibroblast growth factor. J. Cell Biol. 109:1-6.

34. Schultz, G. S., M. White, R. Mitchell, G. Brown, J. Lynch, D. R. Twardzik, and G. J. Todaro. 1987. Epithelial wound healing enhanced by transforming growth- $\alpha$ and vaccinia growth factor. Science (Wash. DC). 235:350-352.

35. Franklin, J. D., and J. B. Lynch. 1979. Effects of topical applications of epidermal growth factor on wound healing. Experimental study on rabbit ears. Plas. Reconstr. Surg. 64:766-770.

36. Callaway, J. L. 1964. Chronic leg ulcers. Classification, differential diagnosis, and treatment. JAMA (J. Am. Med. Assoc.). 186:1080-1081.

37. Krull, E. A. 1985. Chronic cutaneous ulcerations and impaired healing in human skin. J. Am. Acad. Dermatol. 12:394-401.

38. Grillo, H. C., G. T. Watts, and J. Gross. 1958. Studies on wound healing. I. Contraction and the wound contents. Ann. Surg. 148:145-152

39. Zahir, M. 1964. Contraction of wounds. Br. J. Surg. 31:456-461.

40. Joseph, J., and F. J. Townsend. 1961. The healing of defects in immobile skin in rabbits. Br. J. Surg. 48:557-564.

41. Madden, J. W., and E. E. Peacock. 1968. Studies on the biology of collagen during wound healing. I. Rate of collagen synthesis and deposition in cutaneous wounds of the rat. Surgery (St. Louis). 64:288-294.

42. Moncrief, J. A. 1974. Burns. In Principles of Surgery. S. I. Schwartz, editor. Ch. 7, 2nd ed. McGraw-Hill Inc., New York. pp. 253-275.

43. Rappolee, D. A., D. Mark, M. J. Banda, and Z. Werb. 1988. Wound macrophages express TGF- $\alpha$ and other growth factors in vivo: analysis by mRNA phenotyping. Science (Wash. DC). 241:708-712. 